\title{
FRACTURED IDENTITIES IN FICTIONALIZED AUTOETHNOGRAPHIES: AN ANALYSIS OF TONI MORRISON'S A MERCY (2009) AND JUNOT DÍAZ'S THE BRIEF WONDROUS LIFE OF OSCAR WAO (2007)
}

\author{
Rabia Bukhari \\ Lecturer, SBK Women's University, Pakistan rabiabukhari16@gmail.com
}

\begin{abstract}
A major portion of American literary criticism is directed towards an attempt to examine the implications of cultural trauma and resulting impacts on the identity formation of various ethnicities that color the demography of the Americas. The current study attempts to analyze the traumatic cultural experiences of ethnicities that do not belong to the mainstream dominant white culture. In an attempt to decipher the cultural trauma, two seminal works of American fiction are selected. Amongst the selected novels, A Mercy (2009) by Tony Morrison symbolize the experience of women with respect to identity distortion and ethnic subjugation while The Brief Wondrous Life of Oscar Wao (2007) by Junot Diaz is an account of the implications of dictator, Rafeal Trujillato's on the process of identity disruption in those who belong to the HaitianDominican-American diaspora. These divisions of American multicultural panorama, present important dissections that also helps to understand the cultural wars that initiated since the 1980s. There are several common threads that connect the two works, where primarily being autoethnographies, they are culturally representative narratives. Their respective authors have made efforts to display the identity struggles in his/her ethnic group in an otherwise large pool of ethnicities that constitute the vast cultural landscape of the United States. The theory of "Hybridity" by Homi K Bhabha has been taken as a theoretical model for investigations in this study. Qualitative research paradigm has been employed, where analysis has been made through analytical approach, using archival method. It has been found that the collective memories staged in the discussed works point to ethnic differences, where such marginalization has contributed to massive exasperation and atrocities. The current investigation into contemporary American fiction has brought forward the cultural trauma and resulting identity crises experienced by the marginalized sections in an attempt to gain placement in the mainstream landscape.
\end{abstract}

Keywords: Fractured Identities, Fictionalized Autoethnography, Hybridity.

\section{INTRODUCTION}

The novel A Mercy has been authored by Toni Morrison, who is an African American author par excellence, while the second selection for this study The Brief Wondrous life of Oscar Wao is written by DominicanAmerican author, Junot Diaz. Both the novelists have taken up the task of reexamining the past for adding their contribution in correcting the suppressed, muted and undemonstrated histories of immigrants in 
America. The existing and recorded pasts of these ethnic groups picture silenced and/or selectively representative accounts in mainstream American literature. Although framed as fictions, these two novels perform the important task of providing evidence and sharing multilayered level of truth, thus playing the significant role of autoethnographies. Both of the selected works are seminal autoethnographies that represent the collective identity of the author's respective ethnicities under the impact of identity dilemmas. For the purpose of in-depth investigation, this study will analyze the fractured identity in the protagonists of the mentioned works. Identity fractures in the half African, half Portuguese, sixteen year old slave girl, Florens in A Mercy and the ghetto nerd member of the De Leon family, Oscar Wao, who belongs to the first generation of Dominican-Americans in the diaspora, will be traced in terms of their renegotiations of identity, during the course of the novels.

The study will probe the case of individuals belonging to different ethnicities, which have peopled United States as immigrants and have become victims of fractured identities, facing issues in combining the ingredients from their earlier ethnic origins and those from their new place of settlements. When the social and cultural setup inhibits the incorporation of identity ingredients from the old and the new word, individuals are converted into hybrid selves. Diaz and Morrison has caught their protagonists in the middle of existential struggles where they tend to engage in explorations that are aimed at defining their sense of "self". Morrison's work is an insight into the history of slavery that questions the stigma attached to with respect to its attachment with a particularly specified race. The debut novel by Diaz features the impact of DominicanAmerican versions of the effects of dominion in the Caribbean diaspora that was supported by United States and the impact of which has disrupted the process of identity formation in people, whose cultural complexities are brought to observation of cosmopolitan readers.

\section{LITERATURE REVIEW}

Ethnicities that do not belong to the mainstream supremacist culture, i.e., are not white, Protestant or Anglo Saxon has customarily been subject to the debilitating and destructive impacts of cultural trauma. United States of America, which is also synonymous to the "land of immigrants", has seen the rise in discursive debates on the issues entailing multiculturalism from quite some time now. Discussion centering upon the cultural differences-the identity politics has been an important aspect of investigation in the field of Humanities. Where there has been a great influx of novelists from the marginalized sections of society, theorists have also added new ways to explain disputes concerning multiculturalism. Such authors tend to give voice to the collective identities of their respective ethnicities and those of other similar cultural backgrounds that highlight cultural distress. The protagonists of the selected two novels have been analyzed as declarative accounts of the destructive impacts, which are shared by these marginalized groups.

The United States of America in present day as well as in the pre-national times encompasses the capacity of enforcing a harmonious, singular form of identity, followed by all cultures that shapes the ethnic panorama of its lands, for apparently the purpose of unification. Such a conception, in turn initiates the process of acculturation, where people belonging to various cultures are made to enter or follow the mainstream supremacist culture through the development of inclusiveness. This sort of progression presses an undeclared binding upon its adherents to assimilate with the mainstream culture through adoption of components that are its foundational constituents. An agency, which works through this mechanism, entails the executors of the process of acculturation to devise historical accounts that are selected, biased and prejudiced in their approach. They (un)intentionally tend to avoid picturing the painful accounts of communities that are made to assimilate within their group and lose parts of their original ethic identity. Appiah in his work The Ethics of Identity, explains in detail, the longing for transferring our language, religion and folkways to the next generation. According to the author, we highly value the importance of our language, since we don't want to lose the ability to communicate with coming generation and that we care to pass on the philosophy and vision that we have learned of our religion. He further elucidates that all values are held dear to us, since they give meaning to our idea of self, and our understanding of our community. Commenting on the value of culture, he says: "Culture in this sense is the home of what we care about most. If other people organize their solidarity around cultures different from ours, this makes them, to that extent, different from us in ways that matter to us. The result, of course, is not just that we have difficulty understanding across cultures; this is an inevitable result of cultural difference, for much of culture consists of language and other shared modes of understanding, but that we end up preferring our own kind." (2005, p. 71). Forcibly detached from one's root may hinder a normal and successful life for an individual.

For the marginalized strata of society that do not fit into the conventional standards of supremacy, fiction authored by a novelist of their own cultural group may provide an answer to their pleas. Such a novelist has a specific ethos that he weaves into the fabric of his work and it would perform a testimonial account of the identity crises and other types of violence, which are being, inflicted upon the racialized others in a 
multicultural society. In this way the author will be working as a historian, as a social activist, who is bringing to fore, the process of imposed solidarity in which identities are fractured in a society. Thus, the author conveys his testimony for the sidelined and disregarded collective group, to which he himself is a part. This type of literature serves the function of a memorial. In this manner autoethnographic fiction, brings to lime light, the novelist's culture in his fictional demonstration.

Autoethnography is an amalgam, made with the ingredients of both autobiography and ethnography. The writer in autobiography pens down his past life and experiences with the help of hindsight and converts it into a published text. (Bruner, 1993. p. 71). While an ethnographer's work is committed to study of culture, the value systems, beliefs, and communal experiences of the studied group. The main aim of the ethnographer is to aid and supplement the understanding of both the members that belong to the studied group (insiders) and also for those who are strangers to that particular culture (outsiders). (Maso, 2001, p. 136-144).

In the process of designing autoethnography, the researcher, combines the traits of both autobiography and ethnography. He belongs to the culture that he is writing about and holds a specific cultural identity. They not merely record the experiences of their cultural group; rather they also bring forth the analytical aspects of those experiences. Such a process gives shape and meaning to the cultural experience of the studied group and makes it accessible to both insiders and outsiders. This also implies that autoethnographies can claim to have impacts on social change, thus fulfilling the author's purpose. (Bochner, 1997, p 544-621)

In this concept of autoethnographic fiction, apparently the two terms might seem contradictory to each other. This might be the case if one looks at a simpler essentialist definition of fiction as "narrative writing drawn from the imagination of the author rather than from history or fact" (Harmon, 2005, p. 202). A genre that is not founded on historically true or scientifically proven facts. However, this genre with the progress of time has taken into its fold, characteristics that hitherto were not part of its structure. This can be further explained and verified by what may be termed as a corrective definition to the one given by William Harmon. This is a description, which categorizes fiction as means of putting order on thought process and experiences. Mark Spilka notes that "fiction is now often used to describe any literary construction or making -any of the ways in which writing seeks to impose order on the flux of thought or experience" (1978, p. xi)

Therefore an autoethnographic fiction puts order on the experiences of those who are customarily been deprived of mention in the documented accounts. These testimonial accounts bring forward first hand, unadulterated accounts of the complexities and issues faced by their particular culture. During the cultural wars that initiated from the 1950s, there has been an ongoing struggle for authors, novelists and poets to assert the authority to speak for their indigenous groups. Such a right would devalue the writing of a white American author that describes the pangs suffered by cultural traumas in an African American community. Resultantly one might note that majority of the critical voices, giving their discourses on the "blackness" in American literary imagination are from the African Americans. This has given a high rise in the group of autoethnographic authors, (insiders) who pronounce the authority to the authorship of their ethnic circles as an intellectual property entitlement, which gives them the command to give voice to their groups, instead of permitting the mainstream critics (outsiders) to write about their cultures. After the entrance of this movement in the African American sphere, the trend is now establishing in the Caribbean circles while the native authors still lag behind in appealing it. This development is also a challenge to protest the authority of representing the marginalized "others" by the mainstream analysts. Prat has introduced a classification of terms to show the representation by insiders as compared to those with insiders. "[E]thnographic texts are a means by which Europeans represent to themselves their (usually subjugated) others. [. . . .] Authoethnographic texts are those the others construct in response to or in dialogue with metropolitan representations". (Pratt, 1991, p. 33-40)

As a call that answers the implorations made on humanitarian grounds of social justice, autoethnographic literature works with the missionary zeal to bring fore the claims of subdued and restrained voices. Consequently, it makes assertions for impartiality in treatment afforded to them at various levels from, their position in society to their reflection in the written world. Critics can respond to such a demand by making efforts to elucidate and expose the forensic function, epideictic purpose and the deliberative role of autoethnographic fiction. (Nance, 2006, p. 23-24). The "forensic" function entails the procedure employed by authors to correct the inaccuracies in the historical accounts presented about their cultural circles. Thus the author stages and investigation to explore the conditions that resulted in ethnic trauma. (2006, p.22). The second ground of judgement for the autoethnographic text is for its "epideictic" role. This role is determined by examining the extent to which the text forces the audience to classify the depicted incidents as "noble or shamefull" (2006, p. 23). The author has the prerogative to apply such narrative strategies, which would force an intended value judgement on part of the cosmopolitan audience who are probably unaware or misinformed about of the history presented by the forensic fiction. Such an expedition may lead to the 
questioning of collective memories presented by documented recordings and fill in the left out gaps by providing the details of individual trauma.

The third job of autoethnographic fiction is both an extension and a product of the fore mentioned roles of such a text. Texts that successfully corrects history and make the readers sympathetic for injustice done with the divided selves of marginalized communities, also files a petition for some corrective action in reaction to the presentation of an alternate account of facts in front of them. This give the new role of "decision makers" to both the critics and the international readers of the text to decide the future action in line with their judgement.

The present investigation has undertaken the examination of the fractured identities of the protagonists from the mentioned autoethnographic texts and is focused on exposing the realities, which are deliberately kept hidden and overshadowed in front of the cosmopolitan readers. It is both pertinent and useful to consider the following discussion on identity in such communities and then certain theories, which can be employed for attaining such exploration.

Identity provides the basic conception of a person's idea of who he is, and where does he belong. It maps and defines the picture of a character's complete sense of self. Identity also brings into its folds, individual approaches, particular frame of mind and characteristics of a person along with his identification with a greater social group that shares his particular features to some extent. "A person's identity is defined as the totality of one's self-construal, in which how one construes oneself in the present expresses the continuity between how one construes oneself as one was in the past and how one construes oneself as one aspires to be in the future" (Weinreich, p. 300).

A well known critic and author, Kobena Mercer who has gone at length to analyze and decipher the connotations of identity in immigrant communities is of the opinion that journeys taken by immigrants have impacts that run along the course of their lives. Talking about identity, he states that identity is a fluid component, which stays in a continually changing shape, affected by the external and internal influences. He names it a molten phenomenon which is perpetually transforming. He opines that the essentialist conception of identity as a static entity has been confronted by "the experience of doubt and certainty" (Mercer, p. 43)

The postmodern question of identity cannot be restricted to the earlier version of its monolithic and fixed nature of presence. Talking about the theoretical space that is opened up in the present day discussion on identity, Paul Gilory briefs that the components that forms up identity are of wide-ranging in nature, while they also do not exist in a coherent, well-orchestrated manner. He terms identity as a "a changing rather than an unchanging same" (1993, p. 101). In a similar fashion, the conception of identity as presented and articulated by Stuart Hall is appropriate to the present discourse on the non-fixed nature of identity. He posits that identity is "a 'production,' which is never complete, always in process, and always constituted within, not outside of, representation". (1993, p. 222).

In the continuation of the above-mentioned analysis on the non-fixed, shifting fluid nature of identity, the stage is now set to bring in the concept of multiplicity of selves, which has been brought under scrutiny by Homi K Bhabha in his critically acclaimed work, The location of Culture (1994). The work not only records the prejudiced behavior towards the restrained and controlled people, it provides an interesting treatise on the creation of identity that moves forward and backward in a search of its location. Bhabha has given the concept of "Hybridity", which according to Bill Ashcroft and others means, "the creation of new transcultural forms within the contact zone produced by colonization" (Ashcroft, 2001, p. 118). Since its arrival, the concept has received much attention and other scholars like Robert Dale Parker have used the term "the cultural multiplicity" (2008, p. 251) to define duality of being suffered by people, caught in the fix between two cultures. Bhabha in his seminal work talks about the formation of a third space, "unhomeliness", when the migrants try to find a new space, after having suffered the binary fixities between their personal identity and that which has been imposed upon them. Bhabha pleads to consider the struggle and efforts of the colonized for the reverse, hinting at the psychological ambivalence in the bereaved colonized people. After having their stay in the marginal status, the immigrants metaphorically pass the fixed boundaries of the two cultures, and enter the third space where conflicting cultures compete to form new self-conceptions. Bhabha calls into question the fixation of identity by the dominant group upon the dominated group. He opines that hybrid identity of the oppressed is formed in the space of "inbetweeness". He calls this in-between space as "Liminality". This third space place is a dwelling where there is juxtaposition of the culture of the colonizer and the colonized and it is here that the new hybrid identity is being constructed. He calls it "Third Space of enunciation" (1994, p. 54).

The new identity is similar to the previous one but has some definite modifications in it. The scholar has also made use of the term "unheimlich" which also refers to unhomliness. The process of identity formation in 
such a scenario, involves the process of "estranging sense of the relocation of home and the world- the unhomeliness - that is the condition of extra-territorial and cross-cultural initiations" (1994, p. 13).

Timotijevic and Breakwell in their article "Migration and Threat to identity", elaborates the experience of migrants who have been a subject of identity hazard and develop rifts in their sense of self. They have explored the immigrant experience in the perspective of identity changes and formations in post migration scenario. When an immigrant is not provided with continuation of his self-esteem and experiences distinctiveness, then fluctuations in self are bound to follow. They opine: "Being an immigrant, a refugee, a foreigner, a stranger or a guest, are the new labels and categories that one has to deal with...being an immigrant requires dealing with two opposing, but equally derogating representations-that of an intruder (in relation to the host-country) and of a traitor (in relation to the home-culture)...They both reflect distinctiveness based on exclusion" (2000, p. 366).

\section{METHODOLOGY}

I will explore the impacts of identity crises in the selected sample that comprises of the protagonist from the selected works. The character of Florens from A Mercy has been taken, where her experience in the nascent American land has led to a failure of an appropriate identity formation. From the novel The Brief Wondrous Life of Oscar Wao, the character of Oscar De Leon has been selected. The theoretical framework of this study has been provided by Bhabha's theory of Hybridity. The concept of othering and subjugation, which has led to the manufacture of fractured identities in both the central characters of the novel, will be explored under this theory. Both of the novels will also be evaluated as autoethnographic fictions and for the stated forensic, epideictic and deliberative functions that such a text is expected to perform.

The depiction of Identity crises through the behaviour, actions and thought process of selected characters will be analysed. The study will focus on the depiction of immigrant experience of sample characters and their responses to confusions at social, psychological and cultural levels, while impacts on their individual selves regarding identity crises will also be evaluated. The primary source of this research will be the texts of the novel A Mercy and The Brief Wondrous Life of Oscar Wao" I will adopt Qualitative research design for my research and the secondary source of data collection would be books, research journals, articles, magazines and the web.

\section{RESULTS}

This section will primarily map the cultural displacement, subjugation and fractured identities of the protagonists from the two novels while also judging the novels as autoethnographic fictions.

\subsection{Analysis of the Case of African Identity in Pre-National America}

The novel takes the reader back to an unexplored and virgin seventeenth century America, which was yet to be passed over by generations. In 1680 , the location of the story is what would be known as Virginia to the future generations. The story is a montage of many narrative declarations, woven with their experiences; it sheds light on various perspectives of what it was to live in that time, with and without power. The latter supposed to experience all sorts of social and racial discrimination, the development and later modifications of which have been part of America's history and present. The main character is a sixteen-year-old slave girl named Florens. She is taken by Jacob Vaark, an estate owner from Virginia, as payment for an unsettled loan. It was an act of mercy in the eyes of Florens' mother to separate from her daughter instead of her son. Morrison explores the connotations of mercy and freedom, as she states in A Mercy, "To be given dominion over another is a hard thing; to wrest dominion over another is a wrong thing; to give dominion of you to another is a wicked thing" (2009 p. 166-167).

Readers also are acquainted with diverse characters from various ethnic origins, like Jacob Vaark, endeavoring to climb up the social ladder, the Anglo-Dutch plantation owner is the master slaveholder, custodian of the so-called "mercy", who's household in Virginia, symbolizes the microcosm of a multiethnic society. His European mail-ordered wife Rebekka, their servant Lina, who represents the trace of an aboriginal Indian tribe, which had wiped out due to small pox. There is also a mysterious, relatively secluded part of Jacob's pack of slaves, the shipwrecked girl Sorrow, mongrelized descendant of a sea captain. There are also representatives of poor throwaway European cultural nobodies, bonded for their labor to make reimbursement for their Atlantic passage. Willard and Scully are the two gay white indentured servants. Readers also get a chance to know a free unnamed African, respectable ironworker, in possession of knowledge regarding herbal medicine. He is known as the blacksmith, for whom Florens turns into a slave to her heart. All these characters were at the mercy of the wavering mode of life in those times and experiencing multiplicity of identity at various levels. 
Morrison unravels the mysteries of human psychology, being a flag bearer of her gender in terms of issues faced by her kind; she highlights the struggles that her characters underwent in their existential probes. Morrison pictures each character with psychological details. Their behavior and actions are carefully presented to show the major developments that leads to identity disruptions in their lives.

Being a woman in the seventeenth century meant to be under further level of categorizations. The status of an immigrant and a woman makes a very vulnerable setting. Morrison demonstrates what it was like to be a woman in an overly patriarchal society, where religion, law or society provided no protection. Their immigrant status defined distorted identity; the gender status spelled the added sufferings that made them defenseless and made them an irredeemable wound. "To be female in this place is to be an open wound that cannot heal" (161). The author has carefully selected the adjective "open" that defines their unprotected condition, and a "wound" for their state of miseries and suffering and that too in a hopeless state of being incurable.

Florens is the first character that is introduced to the reader. More than any other, character, she occupies the greatest space in the story. Regarding her character, Morrison herself was the opinion that she wanted to evaluate the sufferings of the most vulnerable of creatures in the New World, an African female and a child. A slave on Vaark's household, Florens was transported from a wealthy Portuguese owner as payment of an unsettled debt. What remains a constant pain in her memory is the fact that her mother, that she calls minha mae, in giving preference to her son, parted with her. Her mother was transported from Africa along with the other slaves to keep moving the wheels of economy in the colony. Her early narrations in the novel, describe two very significant possessions. One outstanding variance from the rest of her counterparts was her ability to "read and write". She learned the art from a Reverend father at the Maryland plantation. The second powerful possession is the presence and love of "shoes" in her life. It was not a usual possession for slaves. Morrison makes use of the symbol of shoes to convey figurative messages about the psychological state of Florens. Besides conveying the notions of her traveler status as an immigrant in the colony, they also refer to her aspirations to form an identity like that of her Portuguese lady, whose shoes symbolizes comfort and freedom for her.

Florens being an African slave suffered the trauma of dislodgment and unhomliness. What went away with the leaving of home was her familial connection, the most sacred possession, her mother. Her mother's act of parting with Florens instead of her son, left an permanent wound on the psychological and mental state of Florens. "Please, Senhor, Not me. Take her. Take my daughter" (26). Her tortured sense of identity keeps on trying to find solace. She tries to regain her lost self, one that she was made to leave behind. On the Vaark's farm she receives motherly attention from Lina, another native Indian slave. Yet, her disrupted sense of identity did not get fixed and upon arrival of the blacksmith, she starts doting after him.

Florens craves to fulfill the void that has been left by the loss of her childhood identity. Morrison also explores the impact of maternal abandonment on identity formation. This maternal desertion is in turn again the impact of imperialism, which required slave trade and the predicament of the slaves.

After the affliction of Rebekka with small pox, she sends Florens to fetch the blacksmith, since he had knowledge of herbal medicine and had cured Sorrow. Rebekka also writes her a letter so that she is allowed safe passage through the European colony. Although the wilderness, with its animals and rugged terrain, provided difficulty for her, the townspeople played far more destructive role and left agonizing influences on her identity. After the night's stay, the next morning, the townspeople entered in the house. The widow explained to them that she allowed Florens inside, as she was the "guest seeking shelter from the night" (111).

The treatment of the magistrate and his minions was extremely dehumanizing for Florens. She was unable to comprehend her new status of a human who looked different and "other" to them. It was during her inspection by the Magistrate at widow Ealing's house that Bhabha's indicated process of identity formation in the "third space" initiates, the process includes a clash between two warring ideals in one body. The pain and morbid trauma was elevated further, when one of the townspeople declared quite sarcastically that "I have never seen any human this black" (111). Bystander women behaved as if they had seen a great anomaly and spontaneously evoked God's help for seeing such a creature. Florens tried to show them the letter that Rebekka gave her, the only instrument she had for her safe passage, but no one amongst the visitors at the widow's. Morrison's mention of such episodes provides a commentary on the selective treatment of divinity, which the chosen and elected dominant English have made widespread in the New world, summoning the inference that God they worship is a "White" God while Satan is of "Black" color and the black people around them are minions of Lucifer. "Without touching they tell me what to do. To show them my teeth, my tongue... They look under my arms, between my legs. They circle me, lean down to inspect my feet. Naked under their examination I watch for what is in their eyes" (112-113). 
Her transitory lodging at the house evoked fright and degradation. Some of the people declare her "Afric", thus she was given recognition on the basis of her color-line. Her immigrant status was not allowed a merger. Displaced from home and having received the verbal thrashing for being "this black", along with psychological distress of having to display all her body to prove her human status, Florens enters into the lowest level of nothingness. The experience at the house of widow Ealing rifts her apart, takes away her identity, and makes her a hybrid being. The unrelenting society has denied her the process of assimilation, a merger of social and personal self. She was not treated as a human because she was of a different color and origin from the Europeans that evaluated her.

"Inside I am shrinking. I climb the streambed under watching trees and know I am not the same. I am losing something with every step I take. I can feel the drain. Something precious is leaving me. I am a thing apart...I am a weak calf abandon by the herd, a turtle without shell, a minion with no telltale signs but a darkness I am born with, outside, yes, but inside as well and the inside dark is small, feathered and toothy" (115).

Such fixations induced in her, amplified feelings of unhomliness when a person is made to feel that he is not part of the world and is in the third space where the two warring identities are trying to form a new concept of self (Bhabha 13). The safety mechanism that she employs in this moment of identity distortion is switching her mind to the thoughts of blacksmith. She to tries to seek refuge in anticipating her communion with the blacksmith, who symbolizes a vigorous sense of identity, freedom, power, love and very importantly in this scenario, "home" for her. She feels relief in thoughts of the blacksmith, saying, "I am not afraid of anything now. The sun's going leaves darkness behind and the dark is me. Is we. Is my home."(115). In connection with identity and home, Nyman observes, "the negotiation of identity also involves a redefinition of home" (Nyman, 2007, p. 200).

Thus after her physical and psychological displacement she tries to create a hybrid identity with the estranging sense of repositioning of her home as well as her world. Florens perhaps wants to identify with the free blacksmith, although belonging to her race, the blacksmith maintains a strong sense of self, and Florens sees in him a hope to achieve a vigorous identity. He had a sense of ancestry, which Florens is unaware of; she did not know her family lineage. The blacksmith however, knew his family history, he has been in this profession and so was his father, "and his father before him and back and back for a thousand years" (p. 68).

It provides a good opportunity to analyze the prospects of displacement. She tries to harvest satisfaction by becoming attached to Lina, taking her as mother figure and then becoming an easy target of the advances of blacksmith. The experience proves to purge off Florens from her past pain of being rejected by her mother. Getting physically close with the smithy, she becomes an emotional slave as she considered the blacksmith had freed her from the status of being an excluded and discriminated human, "[y]ou are my shaper and my world as well. It is done. No need to choose" (p.71). Florens also foresees in the blacksmith an opportunity to assimilate her personal and social self, being disrupted by dislocations, rejections and detachments.

After the long journey, when Florens finds the blacksmith, she feels dejected to find out the adopted boy "Malaik" who is now living with him and the blacksmith is not ready to leave him. During her stay she dreams of herself relegating to the state of nothingness. "I dream a dream that dreams back at me... Right away I take fright when I see my face is not there. Where my face should be is nothing" (p.137). She also sees Malaik with her mother, symbolizing the preferential treatment that will lead to her ultimate rejection. Waking up with the agonizingly prophetic dream, she injures the child, offending the smithy and then rejected by him eternally.

This particular episode explains the immigrant situation of Florens. Her identity has been recurrently thrashed. In being rejected by the blacksmith, Florens was prohibited from a future life, where she could assimilate her "two-ness" and merge her wavering identity to one healthy self. It was more torturous for her since she has experienced the pain of a biased treatment earlier. Once more the blacksmith discriminates with her, prioritizes the boy "Malaik" over her. It stimulates a renovation of past pains as she has witnessed such derogatory behavior before. She was abandoned by her mother, thrashed by her mistress, dehumanized by the townspeople, and now finally when the boy Malaik signals the unimaginable and excruciating rejection. She wanted to handover her ownership to the blacksmith signifying the trauma, pain and suffering that she suffered while not being able to fulfil her dream of creating identity with the communion with the blacksmith and finding home. She shatters at his words, "Own yourself, woman, and leave us be....Y You are nothing but wilderness. No constraint. No mind" (p.139).

Florens experiences a destructive loss of self-consciousness for having gone through rejection and denial. She had been barred by the blacksmith, he chooses taking care of the adopted boy, "Malaik" rather than 
living with her. Once more in life, her wandering sense of identity was being deprived of incorporation, halted from unification with a stronger self, a symbolic protection. Florens' journey proves to be a psychological and spiritual flight for her. She thought she would give away her mind and soul to blacksmith, nevertheless the contrary situation takes place and she is purged off her psychological and emotional bondage. She takes the sarcasm literally, when the blacksmith asked her to own herself. She shuns the plan of domesticity, leaves the dream of home, communion and motherhood (unlike Sorrow), adopts her racial identity and decides to write her story, so the world may know history's share in her suffering. She relates:

"There is no more room in this room. These words cover the floor. . . These careful words, closed up and wide open, will talk to themselves. . . Perhaps these words need the air that is out in the world. Need to fly up then fall, fall like ash over acres of primrose and mallow" (p.160-161).

Thus, the iconic possessions, shoes and the ability to write become the vehicles of change in her life. It was with Vaark's left out shoes that Florens undertakes the life-changing journey in the novel. The voyage to fetch the blacksmith, in which she thought she would make herself a mental slave to blacksmith, paradoxically proves to be liberating for her. She gets freedom from her mental servitude, as she no longer requires the blacksmith to complete her identity. She also uses her ability to read and write for recording her story and in this way she becomes one of the historians of that period, making contributions to fill up the gaps in the annals of Americans origins. The shoes that gave her freedom exalted her status from the social standing of the blacksmith. The blacksmith has the unique possession of liberty, he was black yet he was a free man. The smithy however does not possess the reading and writing ability and hence could not make any written contribution and record of his existence. Florens, despite being a black person, frees herself from the psychological and emotional enslavement. She uses her learnings to create her identity. She wants the words of her story to spread out in the world and become one with nature as she herself has assimilated, "I am become wilderness but I am also Florens" (p.161).

Morrison's novel provides the important corrective to historiography that has associated slavery with race. The author has shown that she has removed race from slavery, which means that she has displayed a historical period where we see white slaves (indentured servants) and free black men *(blacksmith). Fulfilling the epideictic role of autoethnographic fiction, Morrison gathers the sympathies of readers for Minha Mae, Florens' mother who decided to part with her daughter as an act of "Mercy" for her. Thus by giving the context and the horrible conditions in which Minha Mae lived on D Ortega's plantation, the rationale behind detachment has been presented as a favorable act of kindness.

\subsection{Analysis of the Case of Dominican-American identity in Post Modern America}

The Brief Wondrous Life of Oscar Wao, authored by Dominican-American novelist Junot Diaz is a tri generational story of the De Leon family. The story encompasses Dominican characters from the Dominican Republic and Dominican American characters, living in New Jersey. The novel brings to fore the muted silenced and largely un-recorded history of the US backed, Trujillo's dictatorship and its impact on the lives of Dominicans who had to migrate to the United States in want of a life of freedom. However as the story unfolds, the readers get to know that there were other challenges awaiting the De Leon family in their diasporic life of New Jersey. Oscar Wao, the protagonist of the story is the third generation of the De Leon family while he is the first generation to have acquired the hyphenated identity of being a DominicanAmerican. The novel unmasks the impact of imperialism while also taking into account the remnants of Spanish colonialism for the part of the story that details trauma of Dominicans. However the mainstay of the story pictures the identity crises of holders of hyphenated-identities, who displaced from their roots and planted in new locations are continuously in a pendulum motion, fixed between the clash of two cultures. The novel is highly imbued with Spanish words and use of "Spanglish to highlight the binaries, inherent in the life of marginalized immigrants.

The subsequent storm in Oscar's life paradoxically initiates with a very normal and stereotypical description of a Dominican American. He is introduced as a "normal' boy who is brought up in a "typical Dominican family" (Díaz 2007, p. 11). The progression in the story brings about the process of hybridization in this character. Where unlike the hyper masculine gender identity of typical Dominican males, he transforms into a nerd, who seeks refuge in the written world.

Oscar's mother, known as Beli had escaped the atrocities of Trujillo's dictatorship by fleeing into United States, but her utopian conceptions were soon disregarded by stark reality of being treated as a racialized other in America. She marries the man, she meets in the plane but her marriage was no relief, it broke down later, leaving her with two kids, Oscar and Lola. Both children could not associate completely with the place of their familial origins, neither could they completely assimilate into their acquired American identity. The character of Oscar presents an interesting case study of fractured identity. He fails to adopt the aura of a 
macho that is so characteristic of Dominican Republic. "dude never had much luck with the females (how very un-Dominican of him)" (2007, p.11). Even in the US, he lives in a slum and is at the margins of both of his cultural and diasporic identities. He fails to put on a display of stereotypical Dominican characteristics. "You ever eat toto? Melvin would ask, and Oscar would shake his head, answer decently... I am Dominican, I am. It didn't matter what he said." (2007, p. 180)

For the adoption of a sense of complete identity, it is very important to have a sense of belonging and a connection with one's familial roots. Oscar's identity fails the test as he could not establish his ancestry and his background. This is what Bhaba has referred to as the feeling of "unhomliness". To fill up the gaps, in what Bhabha calls the "the third space of enunciations" Oscar resorts to nerdy peculiarities, he gets absorbed into science fiction and in the world of super heroes, when he aligns the idea of difficulties, faced by a boy of color in America with impediments faced by super heroes. "[y]ou really want to know what being an X-Man feels like? Just be a smart bookish boy of color in a contemporary US ghetto. Mamma mia! Like having bat wings or a pair of tentacles growing out of your chest" (p. 22)

The reshaping of identity and its transient forms rips Oscar's sense of self. The tendency of acculturation in America, where for the attainment of a unified national identity, people of color are kept at the margins, which generates the feelings of being placed at a low pedestal in front of the supremacist mainstream culture. In trying to extract identity from either of the two cultures which oscillates his identity, he decides to turn back to his roots and visit Santo Domingo. This depicts again what Bhabha has termed as "unhomliness". His summer visit to the island also allows him a chance to adopt the persona of a Caribbean Womanizer, which he could not become in his diasporic life, failing in all the affairs that he initiated. He develops an affair with a prostitute Ybon. "the Higher Power's last-ditch attempt to put him back on the proper path of Dominican male-itude" (2007, p. 283). Oscar had lived an emotionally sacked life in his days in New Jersey. Ybon presents to him the idea of providing an emotional adventure that he has so many times failed to achieve in America. Ybon means a new opportunity to him. "Oscar consider[s] her the start of his real life" (2007, p. 279). It was however unfortunate on Oscar's part that the family curse, "fuku" emerges, as it has tainted the love life of his mother, he could not fulfil the idea of achieving Dominican conception of masculinity. "Fuku" in the novel has been described as a curse on De Leon family. Oscar's grandfather Cabral De Leon had once denied the advances of the dictator, known for his lust for young girls, towards his elder daughter. It was mentioned in the novel that whosoever had incurred the wrath of Trujillo would be under, "fuku", a curse that will render them unlucky in love. Unable to decide the route for his life, Oscar remains indecisive and just the day when he was supposed to return to America from Santo Domingo, he decides to stay. "What do I have waiting for me in Paterson?.. It felt like the right thing to do. Help clear his head and his heart of the gloom that had filled them these months." (2007, p. 279). Throughout his life in America, Oscar remains in a struggle to acquire identity of his true culture. His mother Beli tells him very little about the traumatized past that their origin faced. His forward and backward journey is indicative of his identity quest. It is an effort to transform himself from being a "nobody" in America and join a "nation" with which he could assimilate completely. This is a typical representation of the transient and transforming identity, which according to Bhabha is formed because of cultural crises by immigrants.

Although Oscar could not save himself from the curse that taints his family, he does try to evolve a new identity that is not like either of the two cultures, presented as a choice of attachment for him. Bhabha rightly terms this identity which is unlike the two clashing cultures. While he does not fulfil the standards of Dominican masculinity, that involve multiple numbers of women in their lives, Oscar stands an exception to this standard of Dominican identity. In order to put form in his chaotic conceptions of self he plunges into book world to make sense of his surrounding and aims to author a novel. As a writer who writes twenty to thirty pages a day, Oscar shuns the two worlds and seeks refuge in authorship. It was a struggle and determination, a personal agenda that he decides to follow, when the society that he lives in does not gives him a proper recognition. Thus he is unlike his Dominican ancesters, and also does not completey conform to identity roles prescribe by American culture. Thus Bhabha's description of the new identity, which is "almost the same, but not quite" (1994, p. 123), explains the identity adoption by Oscar.

As far as the placement of this novel as an ethnographic text, is concerned, it justly and aptly presents the historically true and hitherto undemonstrated picture of cultural crises in the community that leads to creation of fractured identities. It is worth mentioning here that the novel performs the forensic function by bringing to record, the absent accounts of Trujillo's dictatorship period that lasted for about thirty one years and its long standing impacts that still shades the realities of Dominicans and Dominican-Americans. Lola, Oscar's sister comments that there are like a thousand Trujillos present in all the Dominican Americans. On part of Junot Diaz, he decries the fact that there is no written account of the atrocities inflicted by the "dingiest" of the dictators, who was not any less fierce than Hitler. Through the voice of his narrator, Younir, considered as an 
alter ego of the author, he opines that: "[w]hat's certain is that nothing's certain...Trujillo and Company didn't leave a paper trail -they didn't share their German's contemporaries' lust for documentation." (2007, p. 243). While invoking reader's sympathies the characters of De Leon family stage a protest against imperialism and the process of acculturation, to which they were subjugated as minorities in America and being displaced immigrants from their parent lands, they could not even feel inclusiveness or sameness in their native lands. The author, Diaz, who himself has lived through the pangs of growing up in a diaspora has parallels to the situation of Oscar, since like the titular hero of the novel he has never been directly exposed to Trujillo but he had to face the impacts, like other members of his community, of living under the dictators long shadow.

The novel stands out in its ability to present historical facts of Trujillo's regime, partly to enrich the details of this period and partly to show the trappings of the De Leon family, which is rendered dysfunctional in the novel. The ruthless and ferocious treatments of Dominicans on their own land are also responsible for the creation of diaspora in America that housed them but failed to guarantee an attainment of a developed and inclusive identity. The travel of Beli, Oscar's mother is representative of the thousands of immigrants who had been dislocated from their native land and shifted to the industrial North in the US. The vicious cycle, initiated by a mass migration from the Dominican Republic, stemming from a dictatorship backed by the United States to a shift of the island's people in the industrial zones, is in itself a domain that poses the questions of "responsibility" and "accountability" for the motivation behind the series of events that eventually created hyphenated and hybrid identities.

\section{CONCLUSION}

The aim of this study has been to examine the process of identity distortions in the protagonists of the selected novels, through an examination made within the theoretical framework of Bhabha's theory of Hybridity, while also evaluating the role these texts have played as autoethnographies. The trauma of duality in selves is a pervasive phenomenon in immigrant communities and causes disruption in the concept of one's self. The problem typifies the scenario when an individual is denied the healthy assimilation of elements that constitutes his identity. In an immigrant, the dislocation from home coupled with inhibitions on expressing the personal self and the dictation of a certain social self by the dominant hegemon, results in disorder of identity. I have analyzed through Bhabha's concept of unhomliness, the impacts that dislocation from home has on individuals. I have tried to show that disability of forming a positive and healthy identity is not restricted to one class, creed, ethnicity or gender for that matter and is an omnipresent phenomenon for all immigrants. This claim is affirmed by the analysis made in two distant parts of history, one is the prenational America and the other located in Post Modern America. It may however be possible that degree of suppression by the dominant community and previous experience of the one suppressed, may produce different degrees of the disorder, but none of the communities can remain immune to the problem. The two novels have showcased the fluidity and flux in the process of identity renegotiations. In their inability to conform to their home and host cultures, the analyzed characters show the manufacture of "a la carte" identities, which do not wholly resemble the two conflicting cultures, in which the victims find themselves. Florens is neither like her mother Minha Mae, nor like her mistress, Rebecca. Her identity is constructed in the third space, where she takes ingredients of both the ethnicities and enters into a novel territory of self conception. Similarly Oscar fails to correspond to masculine standards demanded of him as a Dominican, nor could he completely adapt to the American popular culture. What can be said with certainty about the two victims is that their identity remains in a transient state. Which is referred to as a characteristic of identity formed in the "third space" by Bhabha? A common escape for both Florens and Oscar is their refuge in writing. This act of writing corresponds to the definition of fiction, referred to in this study by Spilka, who hints at the function of fiction as a medium that gives "order" to the thought and observation of the author. This "order" to the chaotic, fractured and traumatized thought process regarding one's identity is what is needed the most by Florens, by Oscar and also by the authors Morrison and Diaz, who have remained and are still part of this cultural crises. Both these novels provide corrections to mainstream historic accounts of their ethnic origins, while gathering reader's sympathies for the atrocities and cultural trauma faced by their respective kinds; they make a plea for social justice.

\section{ACKNOWLEDGEMENT}

This Research project could not have been completed without the grace of Almighty Allah. A special thanks to my supervisor Dr. Bahramand Shah who has been instrumental in my conceptual clarifications and to Dr Mansoor Abbasi for his valuable insights that paved my interest. I may also extend a special note of gratitude for one of a great shaping influence of my life, Dr. Muhammad Islam, Dean Iqra University, Islamabad. The list of mentions also includes my Department's Director, Dr. Noman Sattar, who remained a motivating factor for exploring American history. A special thanks to my family and my friends who have always been a big support for me and without them I could not have ventured for the many projects of my life, which were made 
possible with their encouragement and their never failing confidence in me.

\section{REFERENCE LIST}

Appiah, K. (2005). The Ethics of Identity. Princeton, NJ: Princton UP.

Ashcroft, B. e. (2001). Key Concepts in Post-colonial Studies. London and New York: Routledge.

Bhabha, H. K. (1994). Location of Culture. London and New York: Routledge.

Bochner, A. P. (1984). The functions of Human Communication in Interpersonal Bonding. (A. \&. Caroll C, Ed.) Boston: Allyn and Bacon.

Bruner, J. (1993). The Culture of Autobiography: Construction of self-representation. (R. Folkenflik, Ed.) Stanfors, CA: Stanford University Press.

Díaz, J. (2007). The Brief Wondrous Life of Oscar Wao. New York: Riverhead.

Gilroy, P. (1993). The Black Atlantic: Modernity and Double Consciousness. London: Verso.

Hall, S. (1990). Cultural Identity and Diaspora. (J. Rutherford, Ed.) London, UK: Lawrence \& Wishart.

Harmon, W. \& Hugh, C. (2005). Handbook to Literature. New York: Pearson.

Maso, I. (2001). Phenomenology and Ethnography. (J. L. Sara Delamont, Ed.) Thousand Oaks, CA: Sage.

Mercer, K. (1990). Welcome to the Jungle: Identity and Diversity in Postmodern Politics. (J. Rutherford, Ed.) London, UK: Lawrence \& Wishart.

Morriosn, T. (2008). A Mercy. New York: Random House.

Nance, K. (2006). Can Literature Promote Justice? Nashville: Venderbitt UP.

Nyman, J. (2007). The Hybridity of the Asian American Subject in Cynthia Kadohata's Floating World. In K. a. Nyman, Reconstructing Hybridity: Post-colonial Studies in Transition (pp. 195-230). Amsterdam and New York: Rodopi.

Parker, R. (2008). How to Interpret Literature: Critical Theory for Literary and Cultural Studies. London: Oxford UP.

Pratt, M. L. (1991). Arts of the Contact Zone. Modern Language Association. Retrieved March 16, 2016, from http://www.jstor.org/stable/25595469 .

Spilka, M. (1978). Towards a Poetics of Fiction. Bloomington: Indiana UP.

Timotijevic, L., \& Breakwell, G. M. (2000). Migration and Threat to Identity. Journal of Community \& Applied Social Psychology, 355-372. Retrieved February 2, 2015

Weinreich, P. (1986). Theories of Race and Ethnic Relations. (D.Mason, Ed.) Cambridge: Cambridge University Press.

Winnicott, D. W. (1991). Playing and Reality. New York: Routledge. 